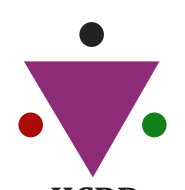

IJCRR

Section: Healthcare

Sci. Journal Impact

Factor: 6.1 (2018)

ICV: $90.90(2018)$

(c) (i) (9)

Copyright@IJCRR

\section{Comparative Study of Manjishtadi Oil and Ashwagandha Oil Matrabasti on Vishwachi (Cervical Radiculopathy)}

\section{Shweta Parwe ${ }^{1}$, Vaishali Kuchewar ${ }^{2}$, Milind Nisargandha ${ }^{3}$, Manoj Patil ${ }^{4}$ S.S. Choudhari ${ }^{5}$}

'Professor, Department of Panchakarma, Mahatma Gandhi Ayurved College Hospital \& Research Centre, Salod (H.), Datta Meghe Institute of Medical Sciences, Wardha, Maharashtra, India; 'Dean, Professor, Department of Kayachikitsa, Mahatma Gandhi Ayurved College Hospital

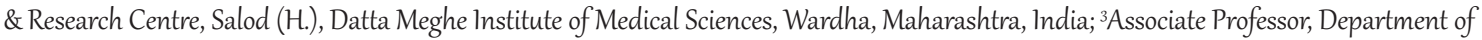
Physiology, Ashwini Rural Medical College, Hospital and Research Centre, Kumbhari, Solapur, Maharashtra, India; ${ }^{2}$ Research Consultant, Jawaharlal Nehru Medical College, Datta Meghe Institute of Medical Sciences (Deemed University), Maharashtra, India; ${ }^{5}$ rofessor, Mechanical Engineering, Yeshwantrao Chavan College of Engineering, Nagpur, Maharashtra, India.

\title{
ABSTRACT
}

Background: Ayurveda suggested many treatments for Vata vyadhi. Cervical problems mimic Vata disorders. Thus the Vata managements of medicated oils through rectal is better management for the identified clinical condition Vishwachi (Cervical Radiculopathy) in the present study. Among such disorders, Ayurvedic classics have described a disease in the name of Vishwachi. The signs and symptoms of Cervical Spondylosis with radiculopathy, such as neck pain radiating to upper limbs, restricted neck movements have been explained in Harrisons Principles of Internal medicine, Davidsons's principles of Internal medicine and Golwalla medicine for students. Because of present-day lifestyles, food, habits, excessive stress-strain and anxiety more people are getting these problems and the incidence of the disease Viswachi is drastically increased day by day.

Aim and Objectives: To study the effect of Manjishtadi oil Matrabasti in Vishwachi (Cervical Radiculopathy). And to compare the effects of Manjishtadi oil and Ashwagandhadi oil Matrabsti on Pain, Tingling sensation and Nerve Conduction Study.

Methodology: Procedure In this examination, 30 patients will be separated haphazardly into 2 groups (15 in each ). In Group A (Control) - Ashwagandhai oil Matrabasti $30 \mathrm{ml}$ will be managed a day after food for 21 days and Group B (Experimental) Manjishtadi oil Matrabasti $30 \mathrm{ml}$ will be controlled a day after food for 21 days. The evaluation will be recorded on 0 and $21 \mathrm{st}$ day.

Results: Changes will be observed in objective outcomes.

Conclusion: Manjishtadi oil will be effective in Nerve conduction parameters.

Key Words: Matrabasti, Vishwachi, Nerve Conduction Study, Cervical radiculopathy

\section{INTRODUCTION}

The present-day world is with more cervical problems as they are habituated with electronic instruments usage and/ or occupational. Thus the avoidance is not possible and a better curative area is to be identified. Ayurveda suggested many treatments for Vata vyadhi. Cervical problems mimic Vata disorders. Thus the Vata managements of medicated oils through rectal is better management for the identified clinical condition Vishwachi (Cervical Radiculopathy) in the present study.

Among such disorders, Ayurvedic classics have described a disease in the name of Vishwachi. The signs and symp- toms of Cervical Spondylosis with radiculopathy, such as neck pain radiating to upper limbs, restricted neck movements have been explained in Harrisons Principles of Internal medicine ${ }^{1}$, Davidsons's principles of Internal medicine ${ }^{2}$ and Golwalla medicine for students. ${ }^{3}$ Because of present-day lifestyles, food, habits, excessive stress-strain and anxiety more people are getting these problems and the incidence of the disease Viswachi are drastically increased day by day.

Cervical radiculopathy is brought about by the pressure and bothering of the cervical spine nerve root in the neck. It is regularly caused either by prolapsed of a between vertebral plate from its ordinary situation in the cervical spine or injury.

\section{Corresponding Author:}

Dr. Shweta Parwe, Meghdoot Apartment, M4, 12, Paloti Road, Sawangi(M), Wardha (MS), India. Contact: 9511659185; Email: drshwetaparve@gmail.com

ISSN: 2231-2196 (Print)

Received: 17.09 .2020
ISSN: 0975-5241 (Online)

Revised: 22.10 .2020
Accepted: 09.11.2020
Published: 30.11 .2020 
Ordinary manifestations incorporate arm agony, deadness as well as shivering in the arm or potentially stretching out into the hand and fingers. The particular neurological indications rely upon which nerve in the cervical spine is influenced. The revealed yearly rate of CR is $83.2 / 100,000$ people $^{4}$ while the detailed pervasiveness is 3.5/1000 people. ${ }^{5}$ Viswachi is one of such condition normally observed influencing around $90 \%$ of grown-ups. In this infection serious and pounding sort of torment which transmits from neck, shoulder, arm, lower arm, and digits is experienced. It is additionally connected with deadness and gauntness of upper appendages and its muscles. Henceforth the examination has been started to assess the progressive administration of Viswachi utilizing Ashwagandha Matra Basti and Manjishtadi matra basti. In this yoga, all chose drugs are having properties which compelling in treating Viswachi.

Without vitiation of Vata, Shoola (pain) cannot be produced. So, Vishwachi has to be considered within Vaatvyadhi. In the chikitsa sutra of Vatavyadhi, many Acharyas advised Basti and Acharya Charaka has mentioned matrabasti as a brumhana Sneha. Basti karma helps to increases the absorption capacity of the colon by its action and finally, it nourishes nerve. Matra Basti is a type of Sneha Basti (oil enema) also known as Anuvasan Basti in Ayurveda. ${ }^{6}$ Moreover, Basti is best to pacify Vata and also for Asthi Gata diseases ${ }^{7}$ asthi being the site of Vata and influences the Purishadhara (asthidhara) Kala (Pakwashaya) ${ }^{8}$ and Asthi Vaha Srotas, the vitiated Vata gets subsided when the asthi is treated with Basti. Pakwashaya, as the main site of Vata, the Basti acts better with its Sneha and Shamaka properties. Hence in the present study, Matrabasti is selected. So, this study is undertaken to evaluate the effects of Manjishtadi oil Matrabasti on Vishwachi.

\section{OBJECTIVES}

To study the effect of Manjishtadi oil and Ashwagandha oil Matrabasti in Vishwachi (Cervical Radiculopathy). We will conduct experiments to,

- $\quad$ study the effect of Manjishtadi oil Matrabasti on Pain, Tingling sensation and Nerve Conduction Study

- $\quad$ study the effect of Ashwagandha oil on Pain, Tingling sensation and Nerve Conduction Study

- compare the effect of Ashwagandha oil and Manjishtadi oil matrabasti on Pain, Tingling sensation and Nerve Conduction Study.

Case definition: A diagnosed Vishawachi subject with symptoms pain in Bahuprusthatha (Dorsal aspect of the upper extremity) and radiating to left or right hand with tingling sensation along with positive Spurling test and Cervical Distraction test.
Research Question: Whether Manjushtadi oil Matra Bas$t i$ is more effective than Ashwagandha oil Matra Basti in Vishawachi?

Hypothesis- Manjushtadi oil Matra Basti is more effective than Ashwagandha oil Matra Basti in Vishwachi because of its composition qualities.

Null Hypothesis- Manjushtadi oil matra Basti are not more effective than Ashwagandha oil Matra Basti in Vishwachi.

\section{MATERIALS AND METHODS}

Trial design: A Randomized Standard comparative clinical trial.

Study setting: The study will be conducted in an academic hospital MGACH \& RC, Salod (H), Wardha.

Composition of trial drugs- All herbs will be purchased an authenticate pharmacy and part of the use of the herb as per textual reference; quantity will be used according to the preparation of oil quatity (Table 1)

\begin{tabular}{|c|c|c|c|c|}
\hline $\begin{array}{l}\text { Sr. } \\
\text { No. }\end{array}$ & $\begin{array}{l}\text { Sanskrit } \\
\text { name }\end{array}$ & Botanical name & Parts used & Quantity \\
\hline 1 & Manjishta & $\begin{array}{l}\text { Rumbiacordifolia } \\
\text { Linn }\end{array}$ & Root & 1 part \\
\hline 2 & Masha & Vingna Mungo & Seed & 1 part \\
\hline 3 & Atamagupta, & $\begin{array}{l}\text { Mucunapruriens } \\
\text { Hook }\end{array}$ & $\begin{array}{l}\text { Seed, root, } \\
\text { pod hair. }\end{array}$ & 1 part \\
\hline 4 & Sahachar & Barleria prionitis & $\begin{array}{l}\text { Panchanga, } \\
\text { leaf }\end{array}$ & 1 part \\
\hline 5 & Ashwagandha & $\begin{array}{l}\text { Withania som- } \\
\text { nifera }\end{array}$ & Root & 1 part \\
\hline 6 & Til & $\begin{array}{l}\text { Sesamum indi- } \\
\text { cum.Linn }\end{array}$ & $\begin{array}{l}\text { Seed, oil, } \\
\text { leaf, root }\end{array}$ & 4 part \\
\hline
\end{tabular}

Eligibility criteria: Age between 20 yrs to 60 years, A diagnosed Vishawachi subject with Cervical compression.

Exclusion criteria: Diabetic neuropathy, Post operated cervical radiculopathy and indicated for surgery and severe giddiness and loss of function

\section{Interventions}

The total duration of the intervention will be the same for both groups which will be for 21 days and fallow up will be on 15 days in both groups (Table 2). 
Table 2: Interventions of both groups

\begin{tabular}{lll} 
& Group A & Group B \\
Sample size & 15 & 15 \\
Intervention & Matrabasti with & Matrabasti with \\
& Ashwagandha oil & Manjishtadi oil \\
Duration & 21 days & 21 days \\
Timing of treatment & After food & After food \\
Follow up & 15 days & 15 days \\
\hline
\end{tabular}

\section{Criteria for discontinuing or modifying allocat- ed interventions}

The subject will be withdrawn from the study if any untoward incidence, features of drug sensitivity or any other disease or problem arises, the subject will be offered free treatment till the problem subsides.

Follow up: 0 and $21^{\text {st }}$ day, $15^{\text {th }}$ day

Primary Outcomes: We will see the impact of matrabasti on pain and shivering sensation when treatment. Information will be communicated as a standard mistake of mean at 5 $\%$ Level of noteworthiness. It is theorized that Manjishtadi oil matrabasti will be as more successful than Ashwagandha oil matrabasti in pain, shivering sensation with no any unfriendly impacts.

Secondary Outcomes: We will see the effect of matrabasti on parameters of nerve conduction study

\section{Statistical analysis}

The progressions from the pattern will be dissected by utilizing Paired and Unpaired ' $t$ ' Test for target standards.

Time duration till following up: The patient will be followed up during treatment 21 days

Follow up period $-0,21^{\text {th }}$ and $15^{\text {th }}$ day

Schedule of enrolment, interventions: Matrabasti will be given from 0 to 21 days

Recruitment: 30 (15 in each group) patient will be selected by straightforward arbitrary testing lottery strategy, and PI will assign and enlist the patient.

Methods: Data collection, management, and analysis

Data collection methods: Assessment criteria

\section{Objective criteria}

Nerve Conduction Velocity, Neck Pain and Disability Index, Cervical rotation of Movement. All parameters will be assessed before and after treatment. All patients will stay at the hospital.

Data management: the information passage coding will be finished by PI
Ethics and dissemination: Research ethics approval; approval from the research ethics committee has taken. NoRef.No.DMIMS (DU)/IEC/Sep 2019/8469

Consent or assent: The made consent will be taken from the patient before starting the assessment. During the investigation, the classification of every patient will be kept up.

Dissemination policy: The information will be dispersed by paper distribution. Creation qualification rules and any proposed utilization of expert scholars.

Informed consent materials: With all the data model assent structure and other related documentation will be given to members.

\section{DISCUSSION}

Vata diseases are commonly expressed in musculoskeletal and neurological disorders. The selected disease condition Vishwachi is a neuro-musculoskeletal disorder. The nerve conduction test or demylination and degeneration are not attributed to vata vyadhi with any measurable parameters. As there were no studies in relation are found to determine the nerve conduction in terms of vata here an attempt is made to evaluate the effect Ashwagandha oil and Manjishtadi oil through MatraBasti for the improvement of nerve conduction. The main purpose of the study is to improve nerve functions and to reduce pain and avoid surgery too. Our one study conducted on sciatica. ${ }^{9}$

The Contents of Manjishtadi oil are Manjishta, Aatmagupta, Sahachar, Masha and Ashwgandha. Manjista is Anti-inflammatory, antioxidant, blood purifier. ${ }^{10}$ Atmagupta is Neuroprotective and Neuro-restorative. ${ }^{11}$ L-DOPA portrayed by an inadequacy in the amalgamation of the synapse dopamine in nerve cell. ${ }^{12}$ Sahachara is commonly used in Neurological disorder. ${ }^{13}$ Masha is anti-inflammatory and nervine tonic..$^{14}$ The fiery reaction includes a mind-boggling exhibit of protein initiation, go-between discharge, liquid extravasations, cell movement, tissue breakdown and fix. Ashwagandha is Neuroprotective, Immunomodulatory and Anti-inflammatory. ${ }^{15}$ Hence according to their actions, they help in breaking pathogenesis.

Agrawal in his study reviewed the Cervical Spine Clearance. ${ }^{16}$ Dangore et al. conducted an evaluation of the efficacy of colour doppler ultrasound in the diagnosis of cervical lymphadenopathy. ${ }^{17}$ Shrivastava et al elaborated on the role of decompression in late presentation of cervical spinal cord disorders. ${ }^{18}$ Interesting rare pathologies of the neck region are also reported. ${ }^{19,20}$ Chandak et al evaluated the efficacy of ultrasonography in the diagnosis of head and neck swellings. ${ }^{21}$ Nagrale et al conducted a study on the efficacy of an integrated neuromuscular inhibition technique on upper trapezius trigger points in subjects with non-specific neck 
pain. $^{22}$ Walia et al conducted microbiology and antibiotic sensitivity of head and neck space infections of odontogenic origin. $^{23}$

Strengths: If Manjishtadi oil matrabasti works then it directly improves nerve conduction parameters. On the off chance that the proposed investigation brings about the positive result, at that point it will give the best equal methodology for the management of Vishwachi with securing and fix nerve capacities.

Limitations: Sample size is small for better results sample size can be added.

\section{CONCLUSION}

Matrabasti is very effective in vatavyadhi and many studies conducted on Vishwachi but comparative Matrabasti still yet not conducted in any such type of study. Hence study will plan. It may be more beneficial and more effective in nerve conduction study as well as others subjective and objective parameters.

\section{REFERENCES}

1. Fauci AS, Braunwald E, Kasper DL, Hauser SL et al edited Harrisons's Principles of Internal Medicine, Volume $1,17^{\text {th }}$ edition, Mc Graw-Hill, Medical Publishing division, Pg1364:116.

2. Boon Nicholas A. editer Davidson's Principles of Internal medicine, $20^{\text {th }}$ edition, reprinted 2006, Publisher's Library of Congress, cataloguing in publication data, Pg1326:1241.

3. Golwalla Aspi F. and Sharukh Golwalla A., editor Golwalla Medicine for students $21^{\text {st }}$ edition 2005; Published by ASPI Golwalla; $\operatorname{Pg} 1212: 587$.

4. Radhakrishnan K, Litchy W, O'Fallon W, et al. Epidemiology of cervical radiculopathy. A population-based study from Rochester, Minnesota, 1976 through 1990. Brain: J Neurol 1994;117(2):325-335.

5. Salemi G, Savettiere G, Meneghini F, et al. Prevalence of cervical spondylotic radiculopathy: a door-to-door survey in a Sicilian municipality. Acta Neurol Scan. 1996;93(2-3):184-88.

6. H. Kasture. Ayurvediya Panchakarma Vigyan $9^{\text {th }}$ ed. Nagpur: Shri Baidyanath Ayurveda Bhavan Ltd. 2006;390-97

7. Ali M, Shukla VD, Dave AR, Bhatt NN. A clinical study of Nirgundi Ghana Vati and Matra Basti in the management of Gridhrasi with special reference to sciatica. Ayu 2010; 31(4): 456-460.
8. Shastri AD. Sushruta samhita. 11th ed. Varanasi: Chaukhambha Academy; 1997.

9. Nisargandha MA, Parwe SD, Wankhede SG, Deshpande VK. Comparison of nerve conduction studies on the affected and non-affected side in the patients of sciatica. Int J Basic Appl Physiol, 2020;9(1):1.

10. Khare CP. Indian Herbal Remedies: Rational Western Therapy, Ayurvedic and Other Traditional Usage, Botany. $1^{\text {st }}$ Edn., Sringer, New York.2004:93-94.

11. Dhanasekaran M, Tharakan B, Manyam BV. Antiparkinson drug Mucuna pruriens shows antioxidant and metal chelating activity. Phytother Res 2008;22(1):611.

12. Zia-Ul-Haq M, Zia-Ul-Haq S. Compositional studies and biological activities of some mash bean (Vigna mungo (L.) Hepper cultivars commonly consumed in Pakistan. Bio. Rese. 2014, 47:23.

13. Soares AR, Marchiosi R, de Cássia RS, de Lima RB, dos Santos WD, Filho OF. The role of LDOPA in plants, Plant signaling and Behaviour. Plant Signal Behav 2014; 9:1-10

14. Usman MR. Anti-Inflammatory, Analgesic And Ulcerogenic Activity Of Vigna Mungo Linn. Leaves, Int J Phytopharmacy 2011;1(2):55-60.

15. Bhatt P, Kushwah AS. Rubia cordifolia Overview: A New Approach to Treat Cardiac Disorders. Int J Drug Dev Res 2013, 5(2): 47-54.

16. Agrawal A. Cervical Spine Clearance: A Review and Understanding of the Concepts. J Nepal Med Asso 2008; 47(4): 24450 .

17. Dangore SB, Degwekar SS, Bhowate RR. Evaluation of the efficacy of colour Doppler ultrasound in the diagnosis of cervical lymphadenopathy. Dentomaxillofacial Radiol 2008;37(4):20512.

18. Shrivastava S, Sakale H, Dulani R, Singh PK, Sanrakhia M. Role of decompression in late presentation of cervical spinal cord disorders. Asian Spine J 2014 Apr;8(2):183.

19. Singh BR, Agrawal A. En-Plaque Meningioma Completely Encircling the Cervical Cord: Case Report. Iran J Radiol 2009; 6(3):e78982.

20. Baisakhiya N, Deshmukh P, Pawar V. Tornwaldt cyst: a cause of neck pain and stiffness. Indian J Otolaryngol Head Neck Surg 2011;63(1):147.

21. Parwe SD, Rajput D, Tadas VR, Nisargandha MA. Efficacy of in Kukkutanda Upanaha Sweda Manyasthambha (Cervical Spondylosis). J Indian Syst Med 2018;6(2):62.

22. Nagrale AV, Glynn P, Joshi A, Ramteke G. The efficacy of an integrated neuromuscular inhibition technique on upper trapezius trigger points in subjects with non-specific neck pain: a randomized controlled trial. J Manual Manipul Ther 2010;18(1):3743.

23. Walia IS, Borle RM, Mehendiratta D, Yadav AO. Microbiology and antibiotic sensitivity of head and neck space infections of odontogenic origin. J Maxillofacial Oral Surg 2014;13(1):16-21. 